\title{
The Effects of Native Shrub, Fencing, and Acorn Size on the Emergence of Contrasting Co-Occurring Oak in Mediterranean Grazed Areas
}

\author{
Roberto Díaz-Hernández ${ }^{1,2}$, José Luis Vicente Villardón ${ }^{2}$, Carolina Martínez-Ruiz ${ }^{3,4}$ (i) \\ and Belén Fernández-Santos $1, * \mathbb{B}$
}

Citation: Díaz-Hernández, R.; Vicente Villardón, J.L.; Martínez-Ruiz, C.; Fernández-Santos, B. The Effects of Native Shrub, Fencing, and Acorn Size on the Emergence of Contrasting Co-Occurring Oak in Mediterranean Grazed Areas. Forests 2021, 12, 307. https://doi.org/10.3390/f12030307

Academic Editor: Jill Thompson

Received: 23 January 2021

Accepted: 2 March 2021

Published: 6 March 2021

Publisher's Note: MDPI stays neutral with regard to jurisdictional claims in published maps and institutional affiliations.

Copyright: (c) 2021 by the authors. Licensee MDPI, Basel, Switzerland. This article is an open access article distributed under the terms and conditions of the Creative Commons Attribution (CC BY) license (https:// creativecommons.org/licenses/by/ $4.0 /)$.
1 Area of Ecology, Miguel de Unamuno Campus, University of Salamanca, 37071 Salamanca, Spain; robdiazh@usal.es

2 Department of Statistics, University of Salamanca, 37071 Salamanca, Spain; villardon@usal.es

3 Area of Ecology, University of Valladolid, Avda. Madrid 50, 34071 Palencia, Spain; caromar@agro.uva.es

4 Sustainable Forest Research Institute UVa-INIA (iuFOR), University of Valladolid, 34071 Palencia, Spain

* Correspondence: belenfs@usal.es

\begin{abstract}
Research Highlights: The regeneration of Quercus species is usually very difficult in many oak woodlands transformed by livestock farming. Some studies have reported that shrubs can facilitate regeneration. However, the strength of interaction may vary depending on, among other factors, the shrub species and the stress tolerance of the oak species. Moreover, further studies are necessary to clarify the relative importance of the two facilitation mechanisms in the same community. Background and Objectives: Cytisus multiflorus (L'Her.) Sweet is a predominant shrub species in the Mediterranean grazed open-oak-woodlands found in the central west of the Iberian Peninsula (bioclimatic limit) and is present with Quercus pyrenaica Willd and Quercus ilex subsp. ballota Samp trees. Thus, we assessed the effect of these native shrubs and acorn size, and the effect of excluding large herbivores, on the seedling emergence of two contrasting co-occurring Quercus species under a bioclimatic limit. Materials and Methods: A manipulative field experiment was carried out considering four treatments as a combination of shrubs (shrub/no-shrub) and fence (fenced/open) factors. A total of twenty plots, five replicates for each treatment were available. In each plot, 20 acorns were sown: 10 acorns (5 small and 5 large) for each Quercus species. Acorn emergence was recorded during the first four years following the sowing. Results: Seedling emergence took place mostly in the spring of the first year after sowing. The presence of shrub was the main significant factor and incremented the emergence of both $Q$. ilex and $Q$. pyrenaica. The effect of the fence depended on the Quercus species considered, improving only the emergence of Q. pyrenaica. A negative effect with the small acorns was detected but only for $Q$. pyrenaica. In all treatments, $Q$. ilex emerged more than $Q$. pyrenaica. Conclusions: C. multiflorus had a clear facilitative effect on the seedling emergence of $Q$. ilex and $Q$. pyrenaica, which was much greater than the physical effect that acorn size and excluding large herbivores had. As such, this native shrub may have a key role in oak regeneration in Mediterranean grazed areas. Furthermore, in these areas of contact between marcescent and sclerophyllous Quercus species, Q. ilex currently emerges more than Q. pyrenaica. This could be indicative of a shift towards more xeric climatic conditions, which could lead to a change in the dominant tree species in the future. However, this change could be modulated by the effects of native shrub and large herbivores.
\end{abstract}

Keywords: shrub cover; Quercus ilex; Quercus pyrenaica; Cytisus multiflorus; emergence; abiotic stress; facilitation; herbivory; Mediterranean environment

\section{Introduction}

Many oak woodlands worldwide have been transformed by livestock farming, giving rise to savanna-like landscapes [1,2] with a predominant pasture matrix of isolated oak 
trees and shrubs. These landscapes have a high biological diversity that is associated with a high structural diversity $[3,4]$ and oak trees are essential for the maintenance of ecosystem services [5]. The largest example of this landscape in Europe is the pastureland in the southwest of the Iberian Peninsula, covering almost 3.5 million hectares [6].

However, these woodlands are suffering dieback of adult trees [7] and the regeneration of Quercus species is found to be generally very difficult [8]. Studies regarding the demographic structures of Quercus populations have confirmed the almost complete lack of juvenile classes. The insufficient regeneration of oak trees has been explained mainly as a consequence of deficient seed dispersal to suitable sites for seedling establishment $[6,8]$. Moreover, reforestation is difficult because of their low rates of survival and growth, especially in the first dry season [9]. Therefore, it is of great interest to identify effective "safe sites" for Quercus regeneration to maintain the stability of these systems.

In the last decades, several studies have concluded that shrubs could play a role in oak regeneration $[3,10,11]$. The positive interaction of these shrubs should be dominant over the competition in communities under high abiotic stress or high consumer pressure [12]. Temporary abandonment and subsequent encroachment by shrubs have been proposed as useful tools to improve tree growth [13]. Numerous empirical studies have reported that shrubs can facilitate regeneration by improving abiotic conditions [14], reducing water stress and positively influencing the emergence and growth [6], or by protecting against herbivores [15-17]. However, few studies have tried to clarify the relative importance of these two mechanisms of facilitation acting simultaneously in the same community [18-20]. Research has also shown that the strength of the interactions may vary depending on other aspects, such as the potential facilitating species $[4,21,22]$, the stress tolerance of these species [22,23], the levels of extreme stress [24], the abiotic stress factor [22], or the performance measure considered $[20,25]$. Therefore, more studies on these aspects are necessary.

Quercus ilex subsp. ballota Samp (sclerophyll; hereafter Q. ilex) and Q. pyrenaica Willd (marcescent) are two species of Quercus frequent in the Iberian Peninsula and their distribution has traditionally been explained by interspecific differences in drought/shade tolerance [26,27]. Q. ilex is well adapted to the Mediterranean subhumid or semiarid conditions, whilst $Q$. pyrenaica is a typical tree species of the Mediterranean-temperate transition in Iberian areas, which occasionally coexists with $Q$. ilex, but it is more moisturedemanding and prefers subhumid and humid Mediterranean conditions [28]. Moreover, in areas with more gentle relief, these forests have frequently been transformed through livestock farming, giving rise to savanna-like landscapes. Therefore, an ideal system to simultaneously test the importance of abiotic/biotic facilitation mechanisms for species with contrasting traits of tolerance to stress under a bioclimatic limit can be found in the Iberian Peninsula. Cytisus multiflorus (L'Her.) Sweet is a dominant shrub species in these systems, whose role in the establishment of Quercus species is not very well known [23]. A positive effect of this shrub species on the initial survival and growth of Quercus seedlings was shown in a planting experiment [20]. However, its effect on the emergence from acorns is unknown (there are no previous studies). On the other hand, it may also be of interest to analyze whether the size of the acorns can influence the emergence. The size of the acorns varies widely both within the same species and among species of Quercus [29], but in general, the acorns mass of $Q$. pyrenaica is higher than that of $Q$. ilex $[29,30]$. The seed mass determines the nutrients that the seedling will have when it germinates and some studies have shown that large seed mass has certain advantages during the early stages of the seedling since it aids in the survival of situations with a low carbon gain, such as shade conditions [29]. Furthermore, large seeds can confer a competitive advantage because they allow access to limited resources, like water, nutrients, or light, and it will promote higher survival [31].

In this study a manipulative experiment was carried out in a Mediterranean grazed area with $Q$. pyrenaica and $Q$. ilex trees, in the domain of the $Q$. pyrenaica tree canopy, to assess the role of the native shrub (Cytisus multiflorus), the acorn size, and the exclusion of 
large herbivore on the seedling emergence of two contrasting co-occurring Quercus species. We predicted that: 1-This native shrub may increase the emergence rates of Quercus species, but this effect may (a) vary with Quercus species; (b) be more pronounced than that of only excluding large herbivores; and (c) be more or less significant depending on the acorn size. 2-There are different patterns between Quercus species for the studied parameters under a bioclimatic limit in Mediterranean grazed areas.

\section{Materials and Methods}

\subsection{Study Site and Species Description}

The field experiment was located in the northwest of the Salamanca region, central west Spain $\left(41^{\circ} 13^{\prime} \mathrm{N}, 6^{\circ} 24^{\prime} \mathrm{W} ; 740-750 \mathrm{~m}\right.$ a.s.l.). The climate is Mediterranean, with $550-650 \mathrm{~mm}$ of mean annual rainfall and $12.4^{\circ} \mathrm{C}$ of mean annual temperature. Rainfall is not distributed evenly throughout the year with pronounced summer drought and great variation between years. The soils are very oligotrophic, acidic, and sandy, with low water holding capacity [20].

The study site was in a transitional area between the $Q$. ilex domain in the east (drier climate) and the Q. pyrenaica domain in the west (more humid climate) [32]. The vegetation consisted of low-density open stand formations of both Quercus species, trees over 60 years old mainly $Q$. pyrenaica, and a herbaceous layer encroached by shrubs, with the leguminous Cytisus multiflorus being the dominant shrub species. These areas are traditionally used as pasture for cattle and sheep under extensive livestock farming; currently, mainly cattle with a high livestock load. Shrubs are frequently burned in small patches and C. multiflorus regenerates well after disturbances and can be classified as a facultative resprouter $[33,34]$. There are also wild species that consume acorns, such as wild boars, jays, and several species of small rodents.

\subsection{Experimental Design}

A field experiment was carried out to analyze the influence of shrub and large herbivore exclusion on Quercus emergence, considering also the size of the acorns. In a Dehesa of 800 ha, five sites (300 m apart) were randomly selected. At each site, four treatments were tested: (1) shrub—fenced (SF), (2) shrub—open (SO), (3) no-shrub—fenced (NF), and (4) no-shrub-open (NO) (see Figure A1 in Appendix A). Then in each treatment one plot of acorns was sown containing 10 large and 10 small acorns of both Q. ilex and Q. pyrenaica (total 100 acorns per treatment).

Large C. multiflorus shrubs, more than $1.5 \mathrm{~m}$ of crown diameter and around $10-15$ years old, were selected as nurse plants. Enclosures $(3.5 \mathrm{~m} \times 3.5 \mathrm{~m})$ were mobile construction fences ( $2 \mathrm{~m}$ high $\times 3.5 \mathrm{~m}$ long, mesh hole: $12 \mathrm{~cm}$ width $\times 22 \mathrm{~cm}$ length) fixed to concrete bases to protect against large herbivores. Open plots had similar dimensions to enclosures.

In October-November 2010, Q. pyrenaica and Q. ilex acorns were collected from nearby forests and stored at $4{ }^{\circ} \mathrm{C}$ until sowed in December 2010. Non-viable acorns (empty or preyed upon by insects) were excluded by floating them in water [35]. The wet weights of acorns were respectively: $3.28 \pm 0.07 \mathrm{~g}$ and $5.50 \pm 0.10 \mathrm{~g}$ for small and large $Q$. ilex acorns, and $5.19 \pm 0.14 \mathrm{~g}$ and $7.94 \pm 0.33 \mathrm{~g}$ for small and large $Q$. pyrenaica acorns.

In each plot, 10 acorns for each Quercus species ( 5 small and 5 large ones) were sown in an area of $60 \mathrm{~cm} \times 50 \mathrm{~cm}, 4$ rows $\times 5$ columns. Acorn size and species were systematically alternated to avoid the possible edge effect and also to favor the identification of the species in the early stages of the seedlings (see Figure A2 in Appendix A). Acorns were buried into the soil at $2-3 \mathrm{~cm}$, and holes were systematically separated from each other by $8-10 \mathrm{~cm}$, with the surface being protected against rodents with a labeled wire mesh $(1.2 \mathrm{~cm}$ mesh width) fixed by nails $[19,36]$.

Acorn emergence was recorded during the first four years following the sowing. Seedling emergence of each species was checked on 19 different dates, every fifteen days during the first six months after they began to emerge (in April) to the end of the first dry season (October) and, afterward, in spring and autumn to complete three more years. 


\subsection{Statistical Methods}

A multifactorial analysis of variance (ANOVA) was done with the emergence values (percentage) obtained at the end of the period of study. The four factors whose effects we wanted to analyze were: factor 1: shrub (levels: shrub/no-shrub); factor 2: fence (fenced/open); factor 3: Quercus species (Q. pyrenaica and Q. ilex); and factor 4: size (acorn size: small/large). The site was added as a random factor. All three-way and four-way interactions were eliminated from the model to avoid overfitting.

For the emergence analysis through the time, a four-way repeated-measures ANOVA was done. Data until June of the second year were included. Only one more emergence was later recorded and the repeated dates with the same frequency of emergence could result in a mask of the significance of the results. All four-way and five-way interactions were eliminated from the model to avoid over-fitting.

Since the assumptions of normality (Shapiro-Wilk's test) and homoscedasticity were not met, data were arcsine transformed. When the ANOVA was significant, pairwise comparisons of means were calculated with Tukey's test. All analyses were performed with IBM SPSS Statistics 25.0 software (IBM Corp., Armonk, NY, USA).

\section{Results}

\subsection{Emergence at the End of the Study Period}

At the end of the study period, the overall percentage of emergence was $77 \%$; the most contrasting average values were $36 \% \pm 13 \%$ for small $Q$. pyrenaica acorns in the noshrub—open (NO) treatment, and $100 \% \pm 0 \%$ for large $Q$. ilex acorns in the shrub—open (SO) treatment.

The multifactorial ANOVA (Table 1) showed significant differences in emergence for the main effect of the shrub factor but without significant interaction with any other factors. The Quercus species factor and the interaction between fence and Quercus species factors were also significant. Therefore, the emergence was significantly higher in the Shrub treatment $(87 \% \pm 3 \%)$ than in the No-shrub treatment $(67 \% \pm 4 \%)$ (Figure $1 \mathrm{~A})$. This positive shrub effect was detected for both $Q$. ilex $(97 \% \pm 2 \% \mathrm{vs} .79 \% \pm 5 \%)$ and Q. pyrenaica ( $76 \% \pm 5 \%$ vs. $55 \% \pm 6 \%$ ) (Figure $1 \mathrm{~B}$ ). Nevertheless, the emergence increase in the shrub compared to the non-shrub treatment was somewhat higher for $Q$. pyrenaica than for $Q$. ilex; the increase ratio was 0.382 and 0.228 , respectively. Moreover, $Q$. ilex emergence was greater than for Q. pyrenaica $(88 \% \pm 3 \%$ vs. $66 \% \pm 4 \%$ ) in both Shrub and No-shrub treatments (Figure 1B), and in open treatments (93\% $\pm 4 \%$ vs. $58 \% \pm 6 \%$ ) (Figure 1C). There was no main effect of the fence factor on emergence when considering both Quercus species together $(78 \% \pm 4 \%$ and $75 \% \pm 4 \%$ in fenced and open treatments, respectively). However, when analyzing the fence $\times$ Quercus species interaction, greater differences between fence and open treatments were observed for $Q$. pyrenaica $(73 \% \pm 5 \%$ vs. $58 \% \pm 6 \%$ ) than for Q. ilex $(83 \% \pm 5 \%$ vs. $93 \% \pm 4 \%)$, with the balance being positive for the first species (Figure 1C). No main effect of the acorn size factor on emergence was detected but in interaction with Quercus species, being significant the differences between small and large Q. pyrenaica acorns $(54 \% \pm 5 \%$ vs. $78 \% \pm 5 \%$ ) but not for $Q$. ilex $(86 \% \pm 5 \%$ vs. $90 \% \pm 3 \%)$ (Figure 1D). The interaction between acorn size and shrub showed that in open treatments the mean emergence values differed more between small and large acorns $(59 \% \pm 7 \%$ vs. $75 \% \pm 5 \%$ ) than in Shrub treatments ( $87 \% \pm 4 \%$ vs. $86 \% \pm 5 \%$ ), although the differences were not significant. 
Table 1. Results of the multifactorial ANOVA for emergence percentage data (arcsine transformed) obtained at the end of the study period.

\begin{tabular}{cccccc}
\hline Source & Sum of Squares & df & Mean Square & F & $p$ \\
\hline Shrub & 1.681 & 1 & 1.681 & 20.016 & $<0.001$ \\
Fence & 0.001 & 1 & 0.001 & 0.012 & 0.915 \\
Quercus species & 2.585 & 1 & 2.585 & 30.770 & $<0.001$ \\
Size & 0.195 & 1 & 0.195 & 2.316 & 0.133 \\
Site & 0.691 & 4 & 0.173 & 2.056 & 0.097 \\
Shrub $\times$ Fence & 0.211 & 1 & 0.211 & 2.509 & 0.118 \\
Shrub $\times$ Quercus & 0 & 1 & 0 & 0.004 & 0.950 \\
Shrub $\times$ Size & 0.183 & 1 & 0.183 & 2.175 & 0.145 \\
Fence $\times$ Quercus & 0.724 & 1 & 0.724 & 8.621 & 0.005 \\
Fence $\times$ Size & 0.008 & 1 & 0.008 & 0.096 & 0.758 \\
Quercus $\times$ Size & 0.064 & 1 & 0.064 & 0.757 & 0.387 \\
Error & 5.460 & 65 & 0.084 & & \\
\hline
\end{tabular}

(A)

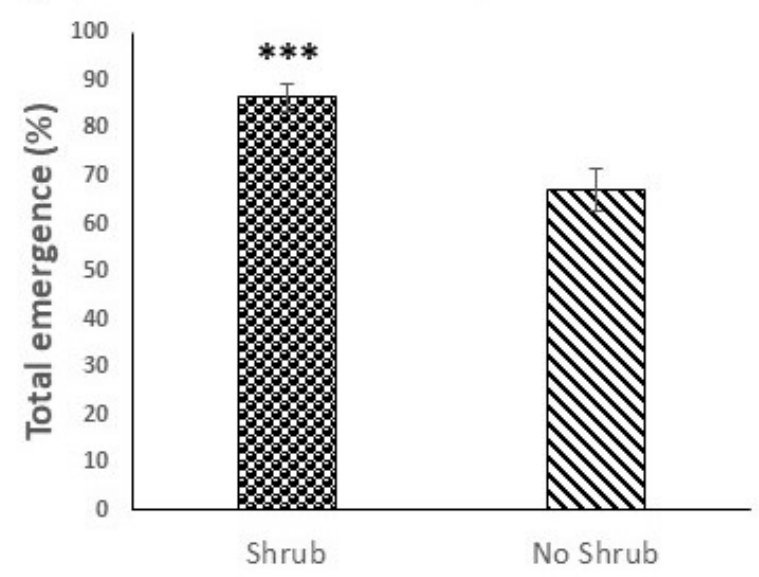

(C)

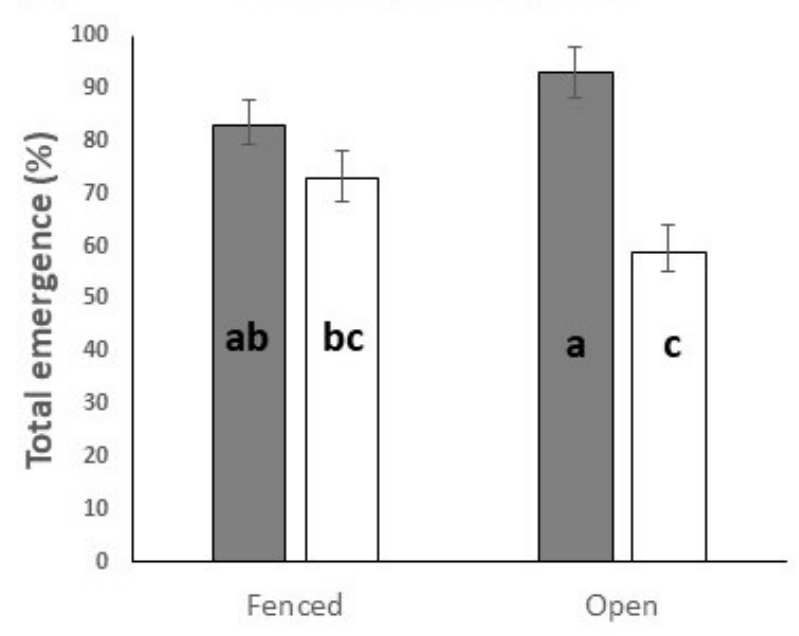

(B) Shrub $x$ Quercus species

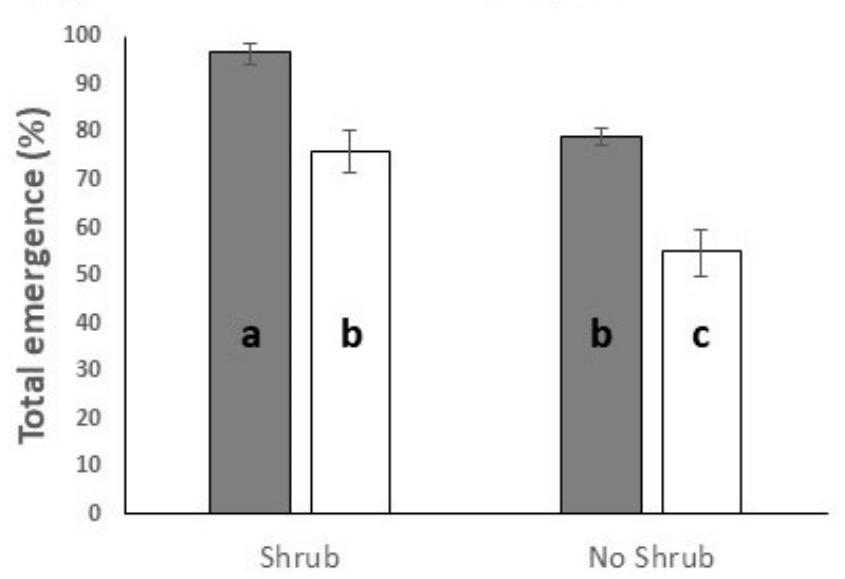

(D)

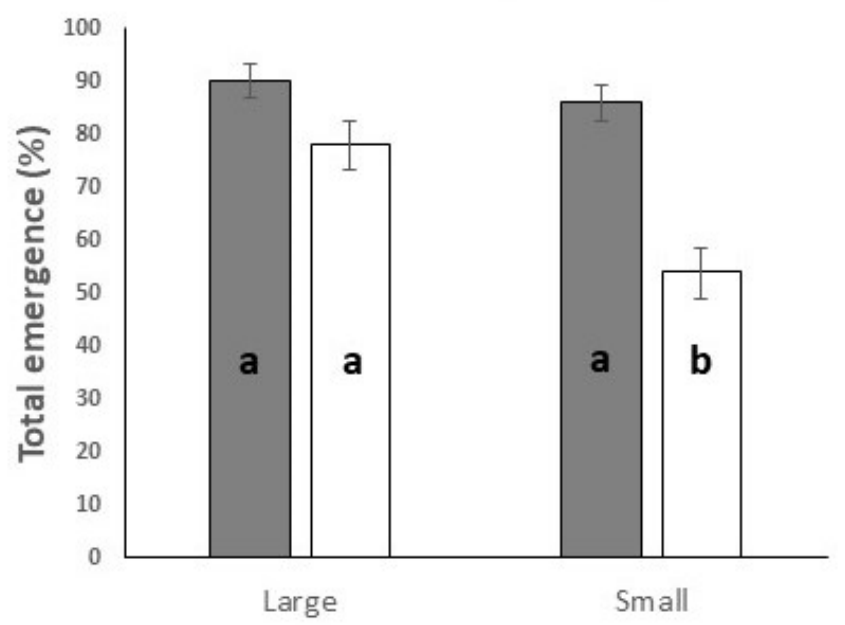

Figure 1. Emergence percentage (mean \pm standard errorE) obtained in each treatment at the end of the study period, for both Quercus species together (A) and each Quercus species (B-D). Grey bars for Q. ilex and white bars for $Q$. pyrenaica. Results after Multifactorial ANOVA are shown. ${ }^{* * *}$ indicate highly significant differences (Tukey test; $p<0.001$ ). With letters results of pairwise comparisons between two-factor interactions; different letters indicate significant differences (Tukey test; $p<0.05)$. 


\subsection{Emergence through the Time}

Seedling emergence began 3.5 months after sowing and $98.4 \%$ of the total emergence taking place from April to October of the first-year. In the following 3 years, only 5 more seedlings emerged, four of them in the spring of the second year and one in the third year (1.3 and $0.3 \%$ of total emergence, respectively).

The repeated-measures ANOVA provided the following results. In the between-subject effects test (without analyzing the interaction with time), significant differences in emergence were only detected for the shrub $(\mathrm{df}=1, \mathrm{~F}=19.471, p<0.001)$ and Quercus species factors $(\mathrm{df}=1, \mathrm{~F}=27.443, p<0.001)$, and for the fence $\times$ Quercus species interaction $(\mathrm{df}=1, \mathrm{~F}=6.264$, $p=0.015$ ). These results, considering the whole temporal process, were like those obtained in the multifactorial ANOVA that used the accumulated emergence data obtained at the end of the study period, which is set out in the previous section (Table 1). In the tests of within-subject effects (Table 2), time was significant, and the two-way interactions of time with shrub, Quercus species, and acorn size. Additionally, two three-way interactions were significant: time $\times$ shrub $\times$ fence, and time $\times$ shrub $\times$ Quercus species.

Table 2. Results of the repeated measures analyses of accumulated emergence values (arcsine transformed) obtained through time.

\begin{tabular}{cccccc}
\hline Source & $\begin{array}{c}\text { Sum of } \\
\text { Squares }\end{array}$ & df & $\begin{array}{c}\text { Mean } \\
\text { Square }\end{array}$ & F & $p$ \\
\hline Time & 85.208 & 13 & 6.554 & 236.622 & $<0.001$ \\
Time $\times$ Shrub & 2.007 & 13 & 0.154 & 5.574 & $<0.001$ \\
Time $\times$ Fence & 0.342 & 13 & 0.026 & 0.95 & 0.5 \\
Time $\times$ Quercus & 1.214 & 13 & 0.093 & 3.37 & $<0.001$ \\
Time $\times$ Size & 0.672 & 13 & 0.052 & 1.867 & 0.03 \\
Time $\times$ Shrub $\times$ Fence & 1.824 & 13 & 0.14 & 5.066 & $<0.001$ \\
Time $\times$ Shrub $\times$ Quercus & 0.791 & 13 & 0.061 & 2.196 & 0.008 \\
Time $\times$ Shrub $\times$ Size & 0.188 & 13 & 0.014 & 0.523 & 0.912 \\
Time $\times$ Fence $\times$ Quercus & 0.529 & 13 & 0.041 & 1.469 & 0.123 \\
Time $\times$ Fence $\times$ Size & 0.054 & 13 & 0.004 & 0.149 & 1 \\
Time $\times$ Quercus $\times$ Size & 0.51 & 13 & 0.039 & 1.415 & 0.146 \\
Error $($ Time $)$ & 24.847 & 897 & 0.028 & & \\
\hline
\end{tabular}

The three-way interaction time $\times$ shrub $\times$ Quercus species (Figure 2A) showed that for both Quercus species emergence took place entirely in the spring with only $1.65 \%$ in September of the first year. $Q$. ilex had greater and faster emergence in the shrub relative to the no-shrub treatment. $Q$. ilex emergence was greater than for $Q$. pyrenaica but in noshrub treatment the significant differences were detected one month later than in the shrub treatments. $Q$. pyrenaica showed significantly greater emergence in shrub than non-shrub treatments by 15 May. For $Q$. ilex the shrub promoted faster emergence and earlier in the spring than for $Q$. pyrenaica.

The three-way interaction time $\times$ shrub $\times$ fence (Figure 2B) showed that 15 days after the start of the emergence, there were already significant differences between open treatments, with shrubs (SO: $44 \% \pm 6.2 \%$ ) and without shrubs (NO: $25 \% \pm 6.3 \%$ ), while no differences were detected between the fenced treatments (SF and NF) during the first month. From 15 May, significant differences appeared between shrub (SF: 86\% $\pm 4.1 \%$ and SO: $78 \% \pm 5.9 \%$ ) and no-shrub treatments (NF: $54 \% \pm 4.8 \%$ and NO: $53 \% \pm 6.7 \%$ ), with no significant fence effect. The emergence stabilized in July and since then, the greatest emergence was found in the SF treatment $(91 \% \pm 3 \%)$, significantly higher than in the noshrub treatments (NF and NO), followed by the SO treatment $(82 \% \pm 5 \%)$ that significantly differed to NF, and finally, the no-shrub treatments $(65 \% \pm 5 \% \mathrm{NF}$ and $69 \% \pm 7 \% \mathrm{NO})$ that did not differ from each other.

The three-way interaction time $\times$ size $\times$ Quercus species (Figure 2C) showed that the acorn size did not have a significant effect on the emergence of $Q$. ilex over time but did for $Q$. pyrenaica. For $Q$. ilex, the emergence for large and small acorns was similar on each 
date, and the accumulated emergence increased until 15 May and then stabilized. For Q. pyrenaica, the emergence was significantly greater for large acorns than for small ones from 1 June. Regardless of the acorn size, the emergence for $Q$. ilex was significantly higher than for Q. pyrenaica from mid-April.

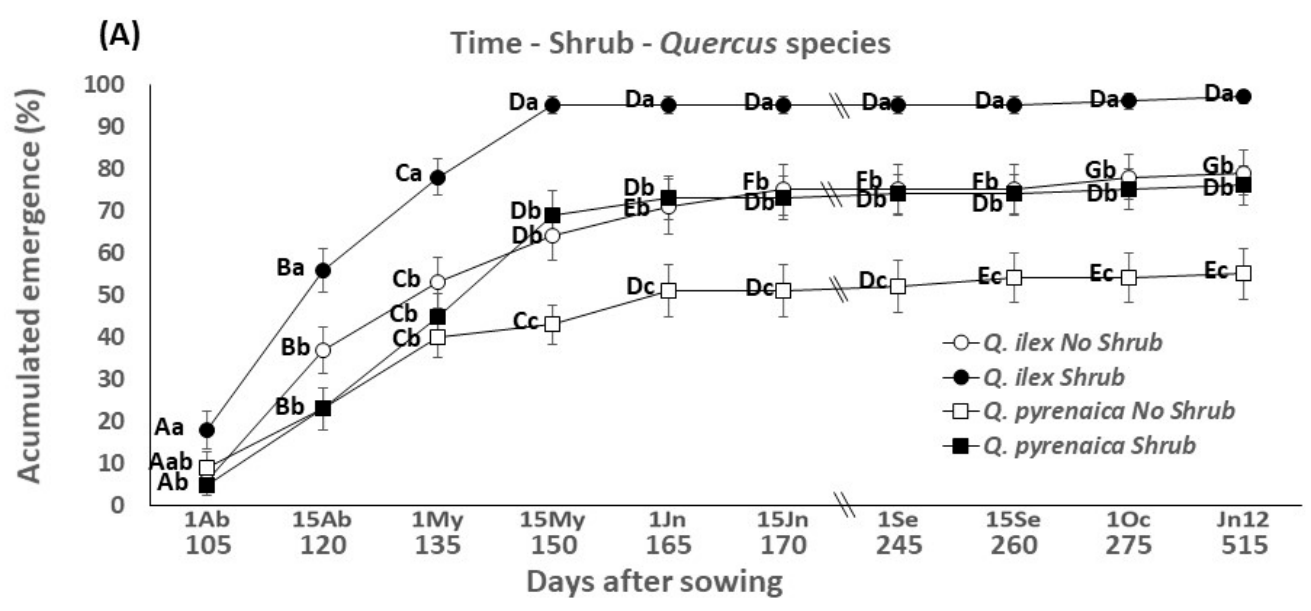

(B) Time $x$ Shrub $x$ Fence
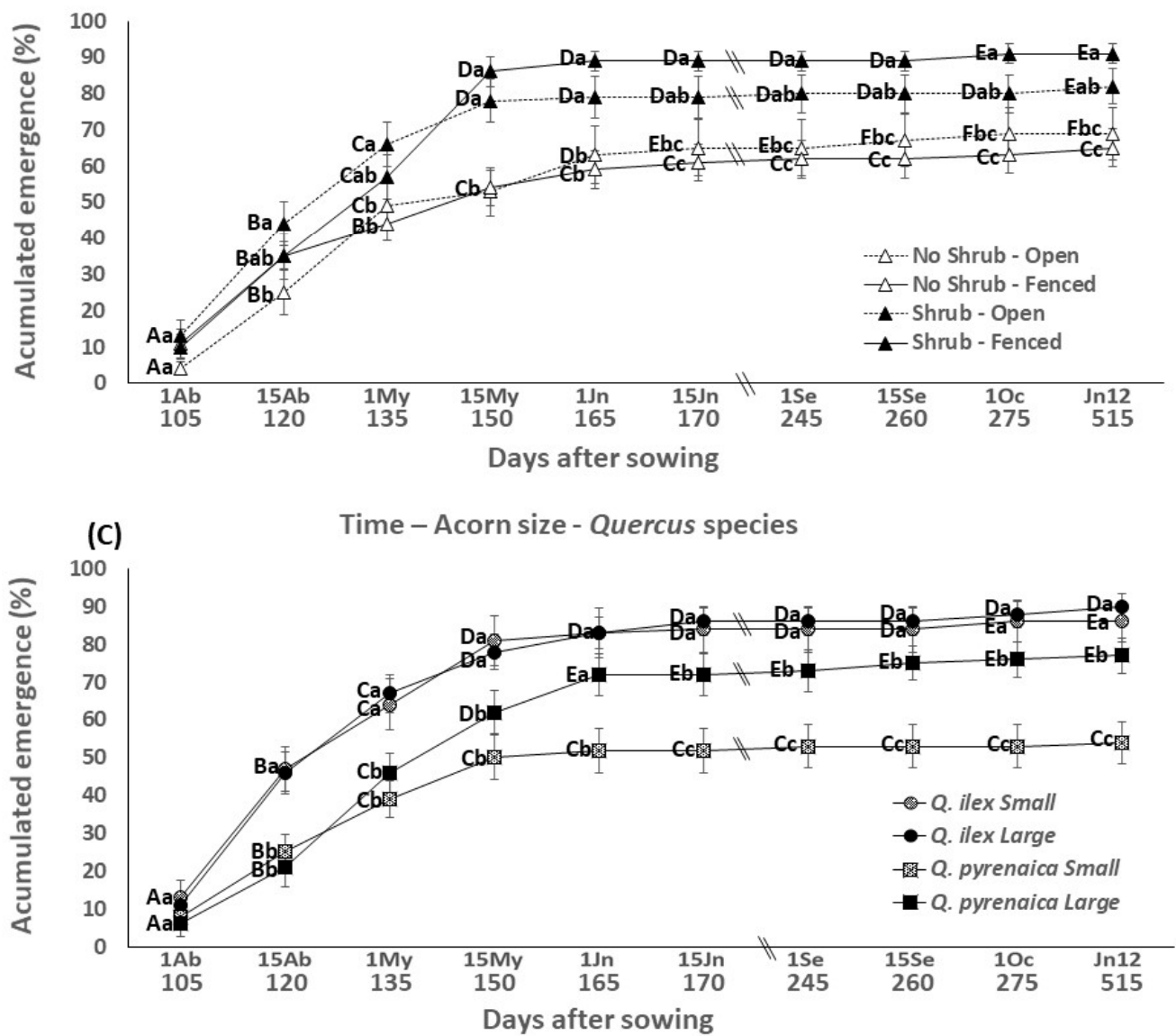

Figure 2. Accumulated emergence values (mean \pm standard error) for each Quercus species and treatment on different dates throughout the first year and a half after sowing. Results after repeated measures analyses are shown. With letters and numbers results of pairwise comparisons between three-factor interactions. Different capital letters indicate significant differences (Tukey test; $p<0.05)$ between dates within the same Quercus-species $(\mathbf{A}, \mathbf{C})$ or treatments $(\mathbf{B})$. Different lower-letters indicate significant differences (Tukey test; $p<0.05$ ) between Quercus-species $(\mathbf{A}, \mathbf{C})$ or treatments $(\mathbf{B})$ at the same date. 


\section{Discussion}

Cytisus multiflorus facilitated the emergence of Quercus ilex and Q. pyrenaica in comparison with non-shrub areas. The positive effect of this shrub species on the acorn emergence of Quercus species has not been published before but on the survival and growth of seedlings of both target Quercus species [20]. The positive effect of other leguminous shrub species on Quercus emergence has also been described in the last decades: Genista hirsuta Vahl [37], Retama sphaerocarpa (L.) Boiss. [4], Genista florida L., and Cytisus scoparius (L.) Link [19]. However, other interesting results are found when evaluating the effect of excluding large herbivores, the acorn size, and the species of Quercus considered.

Regardless of treatment, Quercus emergence in the study area was much higher than in other areas for $Q$. ilex $[4,37]$ and for $Q$. pyrenaica [19]. However, similar emergence values were obtained for Q. pyrenaica in other studies that used mesh protection to prevent acorn predation by small mammals [36]. Mesh protection has proved to be very effective in our study area because the removal of acorns by small mammals was near $100 \%$ when mainly under shrub cover (unpublished data), while high emergence values were obtained using a mesh. Acorn predation by small mammals is a common problem for Quercus regeneration even if acorns are buried [38,39], and mesh protection was also effective in improving acorn emergence $[18,19,36]$. Here, emergence took place mainly during the first spring, and only a minimum percentage of acorns emerged later. It is well known that acorns are recalcitrant and their viability decreases because of dehydration when outdoors for some time [40]. As such, the emergence of Quercus acorns is conditioned by soil moisture [41]. In these Mediterranean areas, soil moisture decreased significantly during the dry summer period because precipitation is very scarce then and the soil is very sandy, with a very low water-holding capacity [20]. We also found that some acorns presented a delayed emergence, as found in other studies [19,36], which happens when germination occurs late due to the summer drought inhibiting their growth until the moisture conditions become optimal again [36].

When analyzing the effect of the different factors, the clearest result was the positive effect of the native shrub, Cytisus multiflorus, on the emergence of both Quercus species, which was higher from the beginning and faster in shrub areas. Other leguminous shrubs have also shown a facilitating effect on the emergence of Q. pyrenaica [19] or Q. ilex [4,39], or on the survival and growth of Quercus seedlings $[4,19,20]$. Our results are most likely due to the significant increase in organic matter and a slightly higher percentage of clay under the C. multiflorus canopy [20], which, in turn, contributed to an increase in soil water-holding capacity that is known to be very important for the germination and emergence of Quercus species $[40,42,43]$. As such, C. multiflorus improves the emergence of Quercus by preventing the drying out of the acorns, like other shrub species [39,44,45], which is very important in Mediterranean areas with a very low water-holding capacity in the soil. C. multiflorus may also have a significant effect by improving other abiotic (microclimatic) conditions, as described for other shrub species [18,39,46,47], or through protection against herbivores, as also mentioned for other species [15-17].

Regarding the use of the fence to exclude large herbivores, interesting interactions were found. The fence favored the emergence of Q. pyrenaica but not that of $Q$. ilex and reduced the differences in emergence between the two species of Quercus. On the other hand, the fence delays emergence differences detection between shrub and non-shrub areas compared to open areas, being higher the emergence under shrubs. This indicates that the shrub had initially (first month since the beginning of the emergence) a protective role against large herbivores. However, later (after the first month), the main effect of $C$. multiflorus was rather the improvement of abiotic conditions, since the fence no longer affects the emergence. Studies in the same area concluded that the main facilitating effect of C. multiflorus on $Q$. ilex and Q. pyrenaica seedling survival was the improvement of abiotic conditions, whereas the fence also affected seedling growth, mainly for Q. pyrenaica [20]. In other areas, no significant effect of the fence was detected on the emergence of $Q$. pyrenaica and Q. petraea seedlings [19]. Many studies show an important effect of rodents, jays, 
and large herbivores on acorn consumption [8,38,48-52]. However, no evidence of acorn predation was found in our study as the protective meshes were not altered and no nearby rodent burrows were observed. The effect of herbivores in the study area is more likely to be caused by trampling, as domestic livestock are very abundant and tend to graze more in areas without shrub. We did not find studies on the effect of trampling on the comparative emergence of these two Quercus species, however, the trampling can compact the soil and alter its ability to absorb or retain moisture $[53,54]$ or may also reduce tree transpiration and growth $[55,56]$. These soil modifications may affect the germination and emergence of $Q$. pyrenaica more than Q. ilex, as $Q$. pyrenaica is less tolerant to the dehydration of its acorns [57] and a water deficit in the development of seedlings [20]. Future studies to shed more light on this topic would be welcome.

By studying the effect of acorn size on emergence, different behaviors were shown in both species. Large acorns of $Q$. pyrenaica showed a higher emergence rate, while for $Q$. ilex no significant effect of acorn size on emergence was found. Other studies also find that acorn size can benefit the emergence of Quercus species [29], specifically $Q$. pyrenaica $[36,58,59]$, whereas for $Q$. ilex, this does not always happen [60] and the relationship may only hold for some maternal plants [36,61]. On the other hand, the positive relationship between acorn size and emergence for Q. pyrenaica only occurs in open areas. It seems that a shrub provides more favorable conditions for the emergence of both species and, in such conditions, the acorn size loses importance. Some studies describe the effects of environmental factors on acorn emergence $[62,63]$ and the positive effect of acorn size on the emergence and establishment in soils with low fertility or other adverse characteristics [64]. However, despite no major advantages of acorn size being observed in this study, especially for $Q$. ilex, it may be important for other aspects of Quercus establishment such as producing larger seedlings with longer roots, which increase the chances of surviving the summer drought [31,65-67], favoring the resprouting after herbivore action [68], or facilitating the establishment of seedlings in shaded environments, where acorns are frequently dispersed by jays and rodents $[38,69]$.

By comparing the two Quercus species, the emergence was always higher for $Q$. ilex than for $Q$. pyrenaica, both with and without shrub. The emergence increase in shrub areas compared to non-shrub areas was somewhat higher for $Q$. pyrenaica than for $Q$. ilex. These results support the idea that positive interactions are relevant for the persistence of mesophytic species at the margins of their distribution areas [70-73]. On the other hand, in shrub areas, the emergence of $Q$. ilex was close to $100 \%$ and the process was faster, with there being the detection of differences with Q. pyrenaica earlier than in open areas. Therefore, even though shrubs in our study site were large and constituted old communities, our results regarding emergence do not support the idea that old shrub formations favor the regeneration of $Q$. pyrenaica against $Q$. ilex, as proposed by other authors [23]. However, in this study, only the emergence was assessed and other important aspects for the establishment of Quercus species should also be considered, such as the survival and growth of the seedlings. In another study in the same area, C. multiflorus favored the survival and early growth of Q. pyrenaica and Q. ilex but to a different degree depending on the variable measured [20]; the marcescent species survival was more favored than the sclerophyllous species, whereas the initial advantage of Q. pyrenaica in terms of growth was attenuated after 2 years.

Given our results, it seems that $Q$. pyrenaica has more problems with the emergence in the study area, the values are lower and emergence, in general, taking place later. In other sites, however, deciduous and marcescent species such as Q. pyrenaica emerged earlier than the evergreen ones like $Q$. ilex $[36,58]$. Even the emergence date appears to be a species-specific character [74], although this can be modified by the maternal source [36]. These differences obtained have surprised us even more since in the area the trees over 60 years old are Q. pyrenaica, with specimens that are even 200 years old, and only a few young trees of $Q$. ilex can be observed. Therefore, the clear advantage in the emergence of $Q$. ilex over $Q$. pyrenaica could be interpreted as a reflection of the change 
towards more xeric conditions that has been taking place for some decades, and that will be even more accentuated in the center of the Iberian Peninsula [75], which, in the future, could lead to a change in the dominant tree species, from marcescent to sclerophyllous. However, although $Q$. ilex is more resistant to water deficit than $Q$. pyrenaica [76], in xeric environments, shrublands can improve the conditions for $Q$. pyrenaica by protecting it from sunlight and photoinhibition [18] and by reducing the demand for transpiration during the dry season [46], as was observed in this area when assessing the initial survival of seedlings [20]. Thus, if other phases of plant establishment, mainly survival and growth, are also considered, the change in the dominant tree species in our areas may be slower if there are shrubs. It would be of great interest to have further studies assess the process of interactions between Quercus species and shrublands in the medium and long term.

\section{Conclusions}

We conclude that in Mediterranean grazed areas, C. multiflorus has a clear facilitative effect on the seedlings' emergence of two ecologically contrasted $Q$ uercus species, $Q$. ilex and $Q$. pyrenaica. The presence of shrub has a much greater effect than the physical exclusion of large herbivores (fence); that is, initially it seems to play a protective role against large herbivores but, after the first month, C. multiflorus seems to play a more important role in modifying abiotic factors. Furthermore, the size of the acorn seems to be less important in the presence of shrub. Therefore, $C$. multiflorus can have a key role in oak regeneration in Mediterranean grazed areas.

On the other hand, in these Mediterranean grazed areas of contact between marcescent and sclerophyllous species of Quercus, with the domain of the Q. pyrenaica tree canopy, $Q$. ilex emergence is currently greater than for $Q$. pyrenaica. The emergence of $Q$. pyrenaica seems to be negatively affected if it is not protected against large herbivores and if the acorns are smaller, which is not the case for $Q$. ilex. This could be indicative of the shift towards more xeric climatic conditions that are taking place, which could lead to a change in the dominant tree species in the future, from marcescent to sclerophyllous, and this change could be more rapid because of pressure from large herbivores. On the other hand, the facilitative effect of C. multiflorus has been found for both oak species but, although it accelerates the process in $Q$. ilex, the increase ratio compared to the emergence outside is somewhat higher for $Q$. pyrenaica. Therefore, the change could be slower if there are shrubs. Therefore, further studies would be necessary to assess the process of interactions between Quercus species and the shrubland in the medium and long term.

Author Contributions: Conceptualization, B.F.-S., C.M.-R.; methodology, R.D.-H., B.F.-S.; software, R.D.-H., B.F.-S., J.L.V.V.; validation, R.D.-H., B.F.-S., J.L.V.V.; formal analysis, R.D.-H., B.F.-S., J.L.V.V.; investigation, R.D.-H., B.F.-S.; resources, B.F.-S., J.L.V.V.; data curation, R.D.-H., B.F.-S.; writingoriginal draft preparation, R.D.-H., B.F.-S.; writing-review and editing, R.D.-H., B.F.-S., J.L.V.V., C.M.-R.; visualization, R.D.-H., B.F.-S.; supervision, B.F.-S., J.L.V.V., C.M.-R.; project administration, B.F.-S.; funding acquisition, B.F.-S.; All authors have read and agreed to the published version of the manuscript.

Funding: This research was funded by the Project SA013G19 from “Junta de Castilla y León", and by the "Programa de financiación de grupos de investigación (2014/00165/001)" from Salamanca University.

Data Availability Statement: Available upon reasonable request.

Acknowledgments: We would like to thank Juan Miguel Gómez-Cuadrado for their assistance in the characterization and location of plots in the field, Sara Villa and David Moro for their invaluable help with fieldwork, and two anonymous reviewers for their valuable comments to improve the manuscript.

Conflicts of Interest: The authors declare no conflict of interest. 


\section{Appendix A}

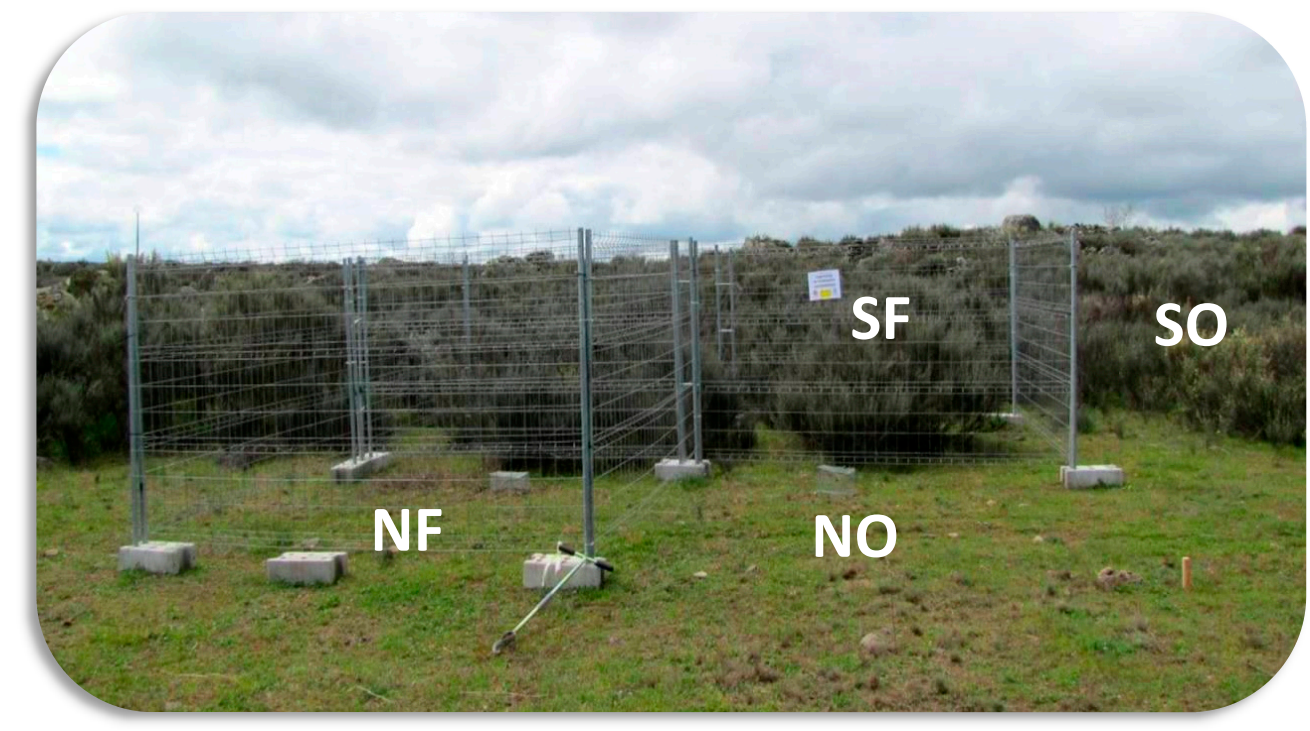

Figure A1. Experimental design in the field. Spatial allocation of the four experimental plots, one for each treatment, considered in each selected area. Shrub—Fenced (SF), Shrub-Open (SO), No-shrub-Fenced (NF), and No-shrub-Open (NO).

\begin{tabular}{|c|c|c|c|c|}
\hline $\mathrm{Qi}_{(1)}$ & $\mathrm{Qp}(\mathrm{s})$ & Qi(l) & Qi(s) & $\mathrm{Qp}(\mathrm{l})$ \\
\hline$Q_{i}(1)$ & $\mathrm{Qp}(\mathrm{s})$ & $\mathrm{Qp}(\mathrm{s})$ & Qi(s) & $\mathrm{Qp}(\mathrm{l})$ \\
\hline Qi(s) & $\mathrm{Qp}(\mathrm{l})$ & $Q_{i}(s)$ & Qi(I) & $\mathrm{Qp}(\mathrm{s})$ \\
\hline Qi(s) & $\mathrm{Qp}(1)$ & $\mathrm{Qp}(1)$ & Qi(l) & $Q p(s)$ \\
\hline
\end{tabular}
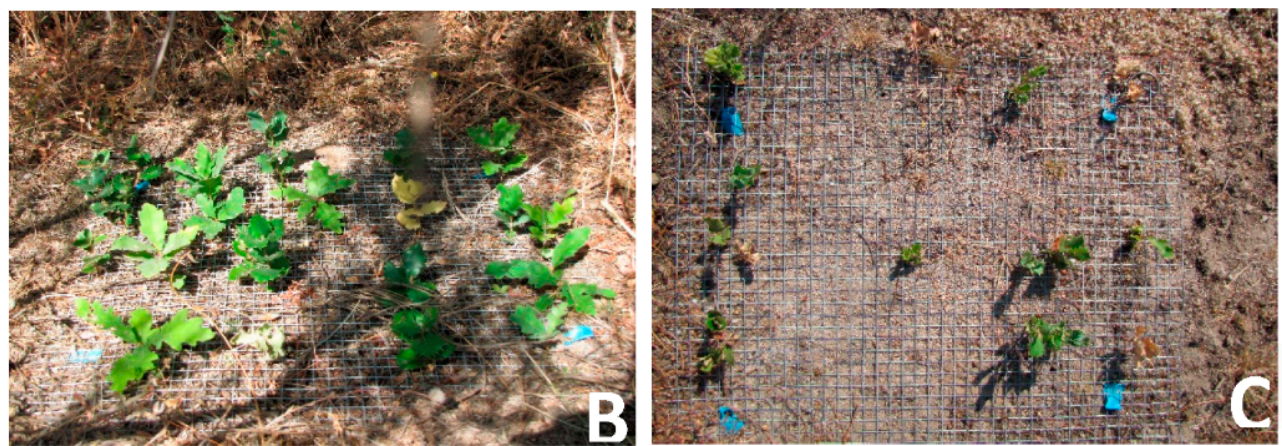

Figure A2. Experimental sowing design carried out in each plot. (A) - Schematic of the basic experimental unit consisted of a 20-hole acorn seeding area in a disposition of 4 rows $\times 5$ columns; five holes with large acorns (1), and five holes with small acorns (s) of each Quercus species. In the first and fourth columns, only seeds of Quercus ilex (Qi) were placed, in the second and fifth columns only acorns of $Q$. pyrenaica (Qp) were placed, and in the third column acorns of both Quercus species were placed. Acorn size and species were systematically alternated to avoid the possible edge effect and also to favor the Quercus species identification in the early seedlings stages. (B)-Seedlings emergence in the Shrub treatment. (C)—Seedlings emergence in the No-shrub treatment. 


\section{References}

1. McCreary, D. Managing and restoring California's oak woodlands. Nat. Areas J. 2004, 24, 269-275.

2. Bergmeier, E.; Petermann, J.; Schroder, E. Geobotanical survey of wood-pasture habitats in Europe: Diversity, threats and conservation. Biodivers. Conserv. 2010, 19, 2995-3014. [CrossRef]

3. Beniston, M.; Diaz, H.F.; Bradley, R.S. Climatic change at high elevation sites: An overview. In Climatic Change at High Elevation Sites; Diaz, H.F., Beniston, M., Bradley, R.S., Eds.; Springer: Dordrecht, The Netherlands, 1997; pp. 1-19.

4. Rolo, V.; Plieninger, T.; Moreno, G. Facilitation of holm oak recruitment through two contrasted shrubs species in Mediterranean grazed woodlands. J. Veg. Sci. 2013, 24, 344-355. [CrossRef]

5. Marañón, T.; Pugnaire, F.I.; Callaway, R.M. Mediterranean-climate oak savannas: The interplay between abiotic environment and species interactions. Web. Ecol. 2009, 9, 30-43. [CrossRef]

6. Plieninger, T.; Bieling, C. Resilience-based perspectives to guiding high-nature-value farmland through socioeconomic change. Ecol. Soc. 2013, 18, 20. [CrossRef]

7. Pulido, F.J.; Díaz, M.; Hidalgo de Trucios, S.J. Size structure and regeneration of Spanish holm oak Quercus ilex forests and dehesas: Effects of agroforestry use on their long-term sustainability. For. Ecol. Manag. 2001, 146, 1-13. [CrossRef]

8. Pulido, F.J.; Díaz, M. Regeneration of a Mediterranean oak: A whole-cycle approach. Écoscience 2005, 12, 92-102. [CrossRef]

9. Navarro Cerrillo, R.M.; Fragueiro, B.; Ceaceros, C.; del Campo, A.; de Prado, R. Establishment of Quercus ilex L. subsp. ballota [Desf.] Samp. using different weed control strategies in southern Spain. Ecol. Eng. 2005, 25, 332-342. [CrossRef]

10. Gómez, J.M.; Puerta-Piñero, C.; Schupp, E.W. Effectiveness of rodents as local seed dispersers of Holm oaks. Oecologia 2008, 155, 529-537. [CrossRef] [PubMed]

11. Pulido, F.; García, E.; Obrador, J.J.; Moreno, G. Multiple pathways for tree regeneration in anthropogenic savannas: Incorporating biotic and abiotic drivers into management schemes: Pathways for oak recruitment in savannas. J. Appl. Ecol. 2010, 47, 1272-1281. [CrossRef]

12. Bertness, M.D.; Callaway, R. Positive interactions in communities. Trends Ecol. Evol. 1994, 9, 191-193. [CrossRef]

13. Porta, J.; López-Acevedo, M.; Roquero de Laburu, C. Edafología Para la Agricultura y el Medio Ambiente, 3rd ed.; Mundi-Prensa: Madrid, España, 2003.

14. Callaway, R.M. Positive Interactions and Interdependence in Plant Communities; Springer: Dortrecht, The Netherlands, 2007.

15. Rousset, O.; Lepart, J. Shrub facilitation of Quercus humilis regeneration in succession on calcareous grasslands. J. Veg. Sci. 1999, 10, 493-502. [CrossRef]

16. García, D.; Obeso, J.R. Facilitation by herbivore mediated nurse plants in a threatened tree, Taxus baccata: Local effects and landscape level consistency. Ecography 2003, 26, 739-750. [CrossRef]

17. Baraza, E.; Zamora, R.; Hodar, J.A. Conditional outcomes in plant-herbivore interactions: Neighbours matter. Oikos 2006, 113, 148-156. [CrossRef]

18. Gómez-Aparicio, L.; Pérez-Ramos, I.M.; Mendoza, I.; Matías, L.; Quero, J.L.; Castro, J.; Zamora, R.; Marañón, T. Oak seedling survival and growth along resource gradients in Mediterranean forests: Implications for regeneration in current and future environmental scenarios. Oikos 2008, 117, 1683-1699. [CrossRef]

19. Torroba-Balmori, P.; Zaldívar, P.; Alday, J.G.; Fernández-Santos, B.; Martínez-Ruiz, C. Recovering Quercus species on reclaimed coal wastes using native shrubs as restoration nurse plants. Ecol. Eng. 2015, 77, 146-153. [CrossRef]

20. Costa, A.; Villa, S.; Alonso, P.; García-Rodríguez, J.A.; Martín, F.J.; Martínez-Ruiz, C.; Fernández-Santos, B. Can native shrubs facilitate the early establishment of contrasted co-occurring oaks in Mediterranean grazed areas? J. Veg. Sci. 2017, 28, 1047-1056. [CrossRef]

21. Rolo, V.; Moreno, G. Shrub encroachment and climate change increase the exposure to drought of Mediterranean wood-pastures. Sci. Total Environ. 2019, 660, 550-558. [CrossRef] [PubMed]

22. Maestre, F.T.; Callaway, R.M.; Valladares, F.; Lortie, C.J. Refining the stress-gradient hypothesis for competition and facilitation in plant communities. J. Ecol. 2009, 97, 199-205. [CrossRef]

23. Madrigal-González, J.; García-Rodríguez, J.A.; Zavala, M.A. Shrub encroachment shifts the bioclimatic limit between marcescent and sclerophyllous oaks along an elevation gradient in west-central Spain. J. Veg. Sci. 2014, 25, 514-524. [CrossRef]

24. Michalet, R.; Brooker, R.W.; Cavieres, L.A.; Kikvidze, Z.; Lortie, C.J.; Pugnaire, F.I.; Valiente-Banuet, A.; Callaway, R.M. Do biotic interactions shape both sides of the humped-back model of species richness in plant communities? Ecol. Lett. 2006, 9, 767-773. [CrossRef] [PubMed]

25. Maestre, F.T.; Valladares, F.; Reynolds, J.F. Is the change of plant-plant interactions with abiotic stress predictable? A meta-analysis of field results in arid environments: Facilitation and stress in arid environments. J. Ecol. 2005, 93, 748-757. [CrossRef]

26. Pigott, C.D.; Pigott, S. Water as a determinant of the distribution of trees at the boundary of the Mediterranean zone. J. Ecol. 1993, 81, 557. [CrossRef]

27. Niinemets, U.; Valladares, F. Shade tolerance, a key plant feature of complex nature and consequences. Annu. Rev. Ecol. Evol. Syst. 2008, 39, 237-257.

28. Rivas-Martínez, S.; Gandullo Gutiérrez, J.M.; Allué Andrade, J.L.; Montero de Burgos, J.L.; González Rebollar, J.L. Mapa de Series de Vegetación de España 1: 400000 y Memoria; Instituto Nacional para la Conservación de la Naturaleza: Madrid, España, 1987.

29. Quero, J.L.; Villar, R.; Maranon, T.; Zamora, R.; Poorter, L. Seed-mass effects in four Mediterranean Quercus species (Fagaceae) growing in contrasting light environments. Am. J. Bot. 2007, 94, 1795-1803. [CrossRef] [PubMed] 
30. Madrigal-González, J.; Ruiz-Benito, P.; Ratcliffe, S.; Rigling, A.; Wirth, C.; Zimmermann, N.E.; Zweifel, R.; Zavala, M.A. Competition drives oak species distribution and functioning in Europe: Implications under global change. In Oaks Physiological Ecology. Exploring the Functional Diversity of Genus Quercus L.; Gil-Pelegrin, E., Peguero-Pina, J., Sancho-Knapik, D., Eds.; Tree Physiology; Springer: Cham, Switzerland, 2017; Volume 7, pp. 513-538. [CrossRef]

31. Lloret, F.; Casanovas, C.; Peñuelas, J. Seedling survival of Mediterranean shrubland species in relation to root: Shoot ratio, seed size and water and nitrogen use. Funct. Ecol. 1999, 13, 210-216. [CrossRef]

32. Luis Calabuig, E.; Montserrat, P. Mapa fitoclimático de la provincia de Salamanca. In Estudio Integrado y Multidisciplinario de la Dehesa Salmantina; Centro Pirenaico de Biología Experimental: Salamanca, España, 1979; Volume 3, pp. 157-181.

33. Fernández-Santos, B.; Gómez-Gutiérrez, J.M.; Moreno-Marcos, G. Effects of disturbance caused by traditional Spanish rural land use on the regeneration of Cytisus multiflorus. Appl. Veg. Sci. 1999, 2, 239-250. [CrossRef]

34. Paula, S.; Arianoutsou, M.; Kazanis, D.; Tavsanoglu, Ç.; Lloret, F.; Buhk, C.; Ojeda, F.; Luna, B.; Moreno, J.M.; Rodrigo, A.; et al. Fire-related traits for plant species of the Mediterranean Basin. Ecology 2009, 90, 1420. [CrossRef]

35. Bonfil, C. The effect of seed size, cotyledon reserves, and herbivory on seedling survival and growth in Quercus rugosa and $Q$. laurina (Fagaceae). Am. J. Bot. 1998, 85, 79-87. [CrossRef] [PubMed]

36. González-Rodríguez, V.; Barrio, I.C.; Villar, R. Within-population variability influences early seedling establishment in four Mediterranean oaks. Acta Oecol. 2012, 41, 82-89. [CrossRef]

37. Smit, C.; Ouden, J.; Vandenberghe, C.; Müller-Schärer, H. Nurse plants, tree saplings and grazing pressure: Changes in facilitation along a biotic environmental gradient. Oecologia 2007, 152, 265-273. [CrossRef] [PubMed]

38. Gómez, J.; García, D.; Zamora, R. Impact of vertebrate acorn- and seedling-predators on a Mediterranean Quercus pyrenaica forest. For. Ecol. Manag. 2003, 180, 125-134. [CrossRef]

39. Smit, C.; Ouden, J.; Díaz, M. Facilitation of Quercus ilex recruitment by shrubs in Mediterranean open woodlands. J. Veg. Sci. 2008, 19, 193-200. [CrossRef]

40. Joët, T.; Ourcival, J.-M.; Dussert, S. Ecological significance of seed desiccation sensitivity in Quercus ilex. Ann. Bot. 2013, 111, 693-701. [CrossRef]

41. Pérez-Ramos, I.M.; Rodríguez-Calcerrada, J.; Ourcival, J.M.; Rambal, S. Quercus ilex recruitment in a drier world: A multi-stage demographic approach. Perspect. Plant. Ecol. Evol. Syst. 2013, 15, 106-117. [CrossRef]

42. Farnsworth, E. The Ecology and Physiology of Viviparous and Recalcitrant Seeds. Annu. Rev. Ecol. Syst. 2000, 31, 107-138. [CrossRef]

43. Gil-Pelegrín, E.; Peguero-Pina, J.J.; Sancho-Knapik, D. Oaks physiological ecology. Exploring the functional diversity of genus Quercus L. Tree Physiol. 2017, 7, 547.

44. Pugnaire, F.I.; Armas, C.; Maestre, F.T. Positive plant interactions in the Iberian Southeast: Mechanisms, environmental gradients, and ecosystem function. J. Arid Environ. 2011, 75, 1310-1320. [CrossRef]

45. Smit, C.; Ouden, J.D.; Müller-Schärer, H. Unpalatable plants facilitate tree sapling survival in wooded pastures. J. Appl. Ecol. 2006, 43, 305-312. [CrossRef]

46. Gómez-Aparicio, L.; Gómez, J.M.; Zamora, R.; Boettinger, J.L. Canopy vs. soil effects of shrubs facilitating tree seedlings in Mediterranean montane ecosystems. J. Veg. Sci. 2005, 16, 191-198. [CrossRef]

47. Muhamed, H.; Touzard, B.; Le Bagousse-Pinguet, Y.; Michalet, R. The role of biotic interactions for the early establishment of oak seedlings in coastal dune forest communities. For. Ecol. Manag. 2013, 297, 67-74. [CrossRef]

48. Perea, R.; San Miguel, A.; Gil, L. Leftovers in seed dispersal: Ecological implications of partial seed consumption for oak regeneration. J. Ecol. 2011, 99, 194-201. [CrossRef]

49. Perea, R.; San Miguel, A.; Martínez-Jáuregui, M.; Valbuena-Carabaña, M.; Gil, L. Effects of seed quality and seed location on the removal of acorns and beechnuts. Eur. J. For. Res. 2012, 131, 623-631. [CrossRef]

50. Del Arco, J.M.; Beltrán, D.; Martínez-Ruiz, C. Risk for the natural regeneration of Quercus species due to the expansion of rodent species (Microtus arvalis). Behav. Ecol. Sociobiol. 2018, 72. [CrossRef]

51. Leiva, M.J.; Fernández-Alés, R. Holm-oak (Quercus ilex subsp. ballota) acorns infestation by insects in Mediterranean dehesas and shrublands: Its effect on acorn germination and seedling emergence. For. Ecol. Manag. 2005, 212, 221-229. [CrossRef]

52. Pérez-Ramos, I.; Marañón, T.; Lobo, J.M.; Verdú, J.R. Acorn removal and dispersal by the dung beetle Thorectes lusitanicus Jeckel: Ecological and evolutionary implications. Ecol. Entomol. 2007, 32, 349-356. [CrossRef]

53. Chaichi, M.R.; Saravi, M.M.; Malekian, A. Effects of livestock trampling on soil physical properties and vegetation cover (Case Study: Lar Rangeland, Iran). Int. J. Agric. Biol. 2005, 7, 1560-8530.

54. Sigcha, F.; Pallavicini, Y.; Camino, M.J.; Martínez-Ruiz, C. Effects of short-term grazing exclusion on vegetation and soil in early succession of a Subhumid Mediterranean reclaimed coal mine. Plant. Soil 2018, 426, 197-209. [CrossRef]

55. Komatsu, H.; Katayama, A.; Hirose, S.; Kume, A.; Higashi, N.; Ogawa, S.; Otsuki, K. Reduction in soil water availability and tree transpiration in a forest with pedestrian trampling. Agric. For. Meteorol. 2007, 146, 107-114. [CrossRef]

56. Ciapała, S.; Adamski, P.; Zielonka, T. Tree ring analysis as an indicator of environmental changes caused by tourist trampling-A potential method for the assessment of the impact of tourists. Geochronometria 2014, 41, 392-399. [CrossRef]

57. Salomón, R.; Lorenzo, Z.; Valbuena-Carabaña, M.; Nicolás, J.L.; Gil, L. Seed recalcitrant behavior of Iberian Quercus: A multispecies comparison. Austrian J. For. Sci. 2012, 129, 182-201. 
58. Urbieta, I.R.; Pérez-Ramos, I.M.; Zavala, M.A.; Marañón, T.; Kobe, R.K. Soil water content and emergence time control seedling establishment in three co-occurring Mediterranean oak species. Can. J. For. Res. 2008, 38, 2382-2393. [CrossRef]

59. Quero, J.L.; Villar, R.; Perez-Ramos, I.M.; González-Rodríguez, V.; Urbieta, I.R.; Gómez-Aparicio, L.; Zavala, M.A.; Marañon, T.; Navarro-Cerrillo, R.M.; Zamora, R.; et al. Implicaciones ecológicas del peso de semilla en especies del género Quercus. Evidencias en condiciones controladas y experimentos de campo. In Proceedings of the $5^{\circ}$ Congreso Forestal Español, Ávila, España; S.E.C.F.-Junta de Castilla y León: Ávila, España, 2009.

60. Gómez, J.M. Bigger is not always better: Conflicting selective pressures on seed size in Quercus ilex. Evolution 2004, 58, 71-80. [CrossRef] [PubMed]

61. Castro-Díez, P.; Puyravaud, J.P.; Cornelissen, J.H.C. Leaf structure and anatomy as related to leaf mass per area variation in seedlings of a wide range of woody plant species and types. Oecologia 2000, 124, 476-486. [CrossRef] [PubMed]

62. Tyler, C.M.; Davis, F.W.; Mahall, B.E. The relative importance of factors affecting age-specific seedling survival of two co-occurring oak species in southern California. For. Ecol. Manag. 2008, 255, 3063-3074. [CrossRef]

63. Mendoza, E.; Dirzo, R. Seed tolerance to predation: Evidence from the toxic seeds of the buckeye tree (Aesculus californica; Sapindaceae). Am. J. Bot. 2009, 96, 1255-1261. [CrossRef] [PubMed]

64. Puerta-Piñero, C.; Gómez, J.M.; Zamora, R. Species-specific effects on topsoil development affect Quercus ilex seedling performance. Acta Oecol. 2006, 29, 65-71. [CrossRef]

65. Metcalfe, D.J.; Grubb, P.J. The responses to shade of seedlings of very small-seeded tree and shrub species from tropical rain forest in Singapore. Funct. Ecol. 1997, 11, 215-221. [CrossRef]

66. Fernández-Santos, B.; Moro, D.; Martínez-Ruiz, C.; Fernández, M.J.; Martín, F.J. Efectos del peso de la bellota y de la edad del árbol productor en las características regenerativas de Quercus ilex subsp. ballota. In Avances en la Restauración de Sistemas Forestales. Técnicas de Implantación; Martínez-Ruiz, C., Lario Leza, F.J., Fernández-Santos, B., Eds.; SECF-AEET: Madrid, Spain, 2013; pp. 198-202.

67. Alonso-Crespo, I.M.; Silla, F.; Jiménez del Nogal, P.; Fernández, M.J.; Martínez-Ruiz, C.; Fernández-Santos, B. Effect of the mother tree age and acorn weight in the regenerative characteristics of Quercus faginea. Eur. J. For. Res. 2020, 139, 513-523. [CrossRef]

68. Green, P.T.; Juniper, P.A. Seed mass, seedling herbivory and the reserve effect in tropical rainforest seedlings. Funct. Ecol. 2004, 18, 539-547. [CrossRef]

69. Bossema, I. Jays and oaks: An eco-ethological study of a symbiosis. Behaviour 1979, 70, 1-117. [CrossRef]

70. Choler, P.; Michalet, R.; Callaway, R.M. Facilitation and competition on gradientes in alpine plant communities. Ecology 2001, 82, 3295-3308. [CrossRef]

71. Castro, J.; Zamora, R.; Hódar, J.A. Restoring Quercus pyrenaica forests using pioneer shrubs as nurse plants. Appl. Veg. Sci. 2006, 9, 137-142. [CrossRef]

72. Wang, D.; Ba, L. Ecology of meadow steppe in northeast China. Rangel. J. 2008, 30, 247. [CrossRef]

73. Madrigal-González, J.; García-Rodríguez, J.A.; Alarcos-Izquierdo, G. Testing general predictions of the stress gradient hypothesis under high inter- and intra-specific nurse shrub variability along a climatic gradient. J. Veg. Sci. 2012, 23, 52-61. [CrossRef]

74. Laliberté, E.; Bouchard, A.; Cogliastro, A. Optimizing hardwood reforestation in old fields: The effects of treeshelters and environmental factors on tree seedling growth and physiology. Restor. Ecol. 2008, 16, 270-280. [CrossRef]

75. Moreno-Rodríguez, J.M. Principales Conclusiones de la Evaluación Preliminar de los Impactos en España Por Efecto del Cambio Climático; Departamento de Ciencias Ambientales, Universidad de Castilla-La Mancha (UCLM): Toledo, España, 2005; pp. 1-35.

76. Plieninger, T.; Rolo, V.; Moreno, G. Large-scale patterns of Quercus ilex, Quercus suber, and Quercus pyrenaica regeneration in Central-Western Spain. Ecosystems 2010, 13, 644-660. [CrossRef] 